\author{
SCENTIA INTERNATIONAL ECONOMIC REVIEW \\ Volume 1 - Issue 1 - 2021
}

\title{
A critical Analysis of the current state of research on the topic of business succession
}

- Considering the company analysis, as well as the need to consider a successor

Jürgen Weltermann, Comenius University, Bratislava, Slovakia Lubomira Strazovska, , Comenius University, Bratislava, Slovakia

\begin{abstract}
In the next few years, many companies in the field of small and medium-sized enterprises (SMEs) in Germany are about to change the generation of entrepreneurs. This article deals with the reasons and strategies for regulated succession of entrepreneurs in these SMEs. The following research question is at the heart of the present study: 'What are the reasons and strategies for finding a business successor considering the company analysis for small and medium-sized enterprises in Germany?'. Within the scope of an extensive literature analysis, the current state of research on the topic of business succession is analysed by a qualitative content analysis according to Mayring and the most important reasons and strategies are identified. For this purpose, 4 main codes and 14 subcodes were defined inductively and deductively, and the present literature was encoded according to the method of structured content analysis. 673 codings were carried out and then analysed in the context of the research questions.

The main reasons and strategies were identified, and the research question was fully answered. In addition to answering the central research question, the article also makes recommendations for the planning and complete implementation of a regulated business succession within the framework of the article conclusion. This article is the author's second article on the topic of Business Succession and is complementary to the author's first article.
\end{abstract}

Keywords: Entrepreneurial succession SMEs, succession scheme SMEs, Business successor, strategies for succession

JEL codes: D00, D01, M20 


\section{Introduction}

2020 is the year of an ever-changing economic world, due to global and national economic crises (e.g. trade barriers due to the unilateral termination of long-term reliable trade agreements, a more pronounced decline in the labour force potential) [5] and sudden severe economic upheavals due to the COVID-19 pandemic, forcing national and international economies to radically adapt micro- and macroeconomic developments.

Especially in Europe and here, with the focus on industrial and agricultural areas and the lack of increasingly necessary raw materials today, small, and medium-sized enterprises shape the corporate landscape.

Small and medium-sized enterprises in Germany are enterprises with less than 500 employees and an annual turnover with less than 50 million $€$ (definition of the IFM, Bonn) employees. As of December 31, 2017, these companies employ approximately 24.19 million employees subject to social security contributions, including trainees in Germany, which is $78.6 \%$ of all employees

Most of these holdings are family-owned enterprises which either manage their enterprises as partnerships or corporations. In exceptional cases, also in a mixed form, the so-called business divisions, in which the operating company is a corporation, and the ownership company is a partnership.

These family companies are bound to be followed up, although in fewer and fewer cases these are family members. This is for many reasons, which are also mentioned in the following. This situation makes it difficult to succeed a planned entrepreneur because a non-family member does not know the company to be taken over and, in this respect, an even more precise planning with an extraordinary amount of information must be prepared and made available. This also applies to cases in which employees of the company take over the company, although this situation is also becoming less and less relevant. [23]

The aim of this article is, therefore, on the one hand, to raise awareness of this issue among entrepreneurs and potential successors and, on the other hand, to aid with such projects.

\section{Methods}

The purpose of this article is to answer the following research question:

\section{'What are the reasons and strategies for finding a business successor considering the company analysis for small and medium-sized enterprises in Germany?'}

In answering this research question, attention will be paid to the following aspects of the current state of research on the subject:

- What are the reasons for finding a successor?

- What possible strategies are being developed in the context of corporate succession?

- What are the possibilities of the transfer of companies?

In order to answer the proposed research question, an extensive literature research and a qualitative literature analysis were carried out. 
For this purpose, the following databases/library catalogues were used for literature research:

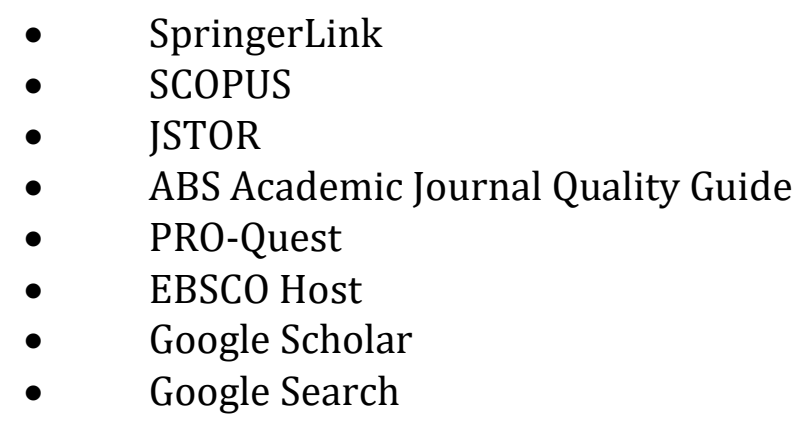

The following search terms were used as part of a targeted literature search.:

- $\quad$ Entrepreneurial succession

- $\quad$ Strategies for Business Succession

- $\quad$ Succession regulation Company

- $\quad$ Succession scheme Company transfer

- Reasons for Business Succession

- Reasons for Business Succession Regulation for Small and Medium-Sized Enterprises

- $\quad$ Motivation Succession regulation for medium-sized enterprises Germany

- $\quad$ Business transition SME Germany Reasons Strategies

- Entrepreneur Succession Reasons Strategies for Small and Medium-Sized Enterprises Germany

Literature research identified 453 potential sources, 157 of which were identified as relevant sources. All sources which met the generally valid scientific requirement of the level of detail and the quality of the preparation were considered relevant. Twenty-five primary sources were used in this work. These are all scientific publications and articles in scientific journals. These are mainly recent works with a release date of more than 2000. The latest work is the journal article from Xian 2021 [28].

This literature was encoded with the MaxQDA software. For this purpose, 4 main codes and 14 subcodes were defined inductively and deductively, and the present literature was encoded according to the method of structured content analysis. To this end, 673 codings were carried out and then analysed in the context of the research questions.

For an overview of the codes and subcodes created and their hierarchy, see Figure 1. 


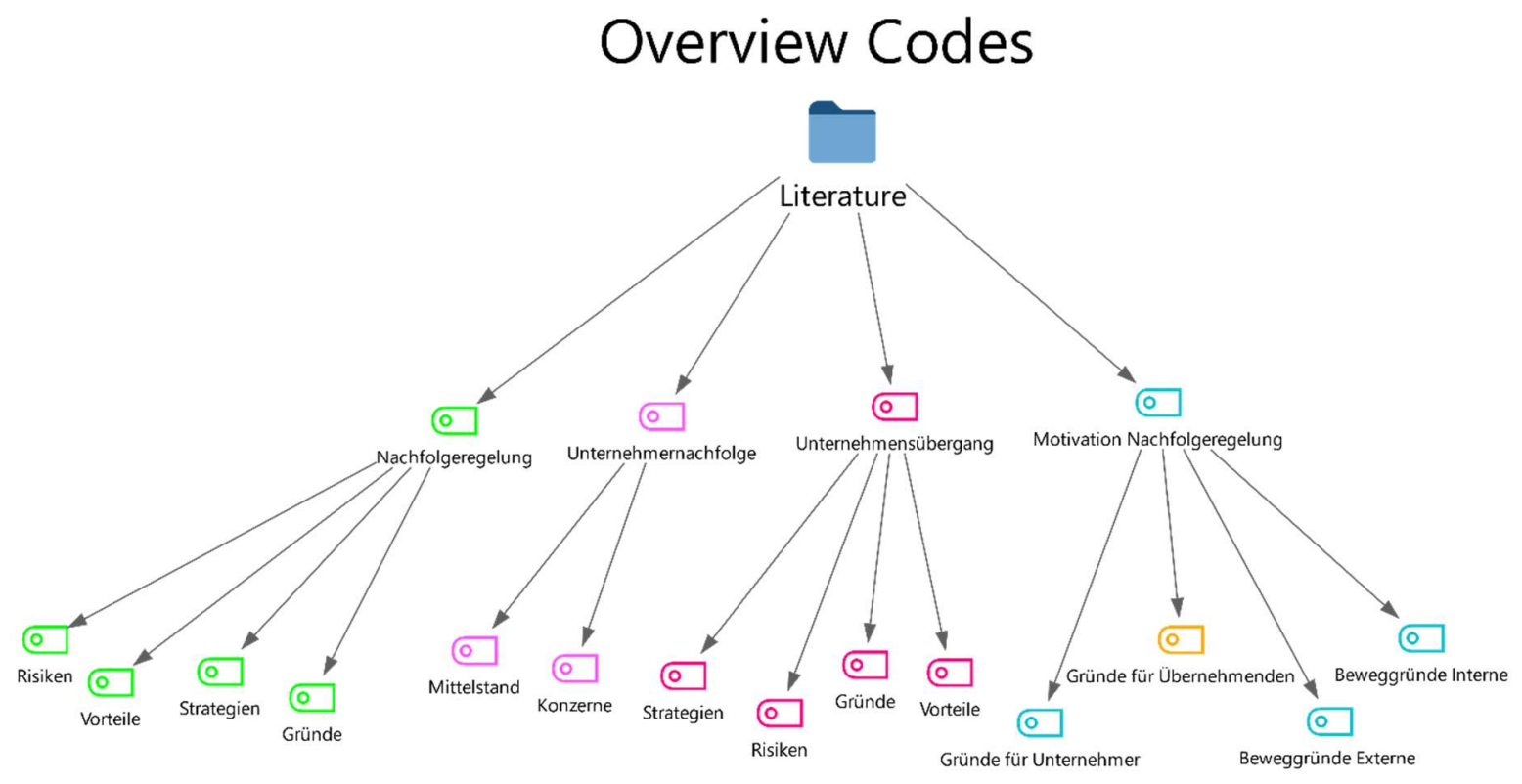

Figure 1: Overview of literary codes ${ }^{1}$

The present study is based on a medium-sized company that is characterized by the following factors:

- Analysis and evaluation of the company

- Analysis of the tax framework

- Financing considerations

- Finding the successor

\section{Results}

The following results were found by the literature analysis.

\section{Analysis and evaluation of the company}

- Determination of company potentials

- $\quad$ Analysis of vulnerabilities

- Valuation of the company

-Substance value methods

-Liquidation value proceedings

-Income value method

-Mean method

-Proceedings under the capital service limit

- Creation of business plans

\footnotetext{
${ }^{1}$ Categories and Codes are presented in the original language of the performed search: German
} 


\section{Determination of company potentials}

An analysis and documentation of the company's success potential, such as employee qualification, Quality of the products / brand name, company know-how, market position, quality of customer and supplier relationships, innovative capacity, etc. is of great value not only for the entrepreneur, as he can thereby substantiate his purchase price claim, but also for the successor, since the latter thus acquires greater certainty about the objective chances of success of the company as well as precise knowledge of how strongly the company's success is tied to the person of the departing entrepreneur. [6]

\section{Analysis of vulnerabilities}

Weaknesses in the organisational area can be seen in the following areas, among others:

- $\quad$ poorly efficient communication

- $\quad$ bureaucratic procedures, so that there is little flexibility

- Unclear organisation

- $\quad$ Discrepancy between responsibility and responsibility

- $\quad$ Too little customer orientation in order processing

- $\quad$ high turnaround times in the operational sub-areas

- too large storage

- Quality problems

These vulnerabilities often correspond to a mostly authoritarian leadership style and possibly relatively low qualifications.

A review of the market position could show the following results:

- $\quad$ Customer loyalty is not sufficient

- $\quad$ Customers purchase the same or similar product

- $\quad$ The competing products are not sufficiently known

- $\quad$ The market demands further developed products

- The market share is too small, although the company is one of the technology leaders

- $\quad$ Broader application of existing know-how in neighboring, previously untapped areas

- $\quad$ New markets have not yet been opened up

- The good product name is not marketed enough

Such findings point to untapped potential of the company.

Deficiencies in organizational structure and business processes have a direct impact on the valuation of the company through the profitability and financing of the purchase price.

These two aspects are directly related to the personnel structure of a company, since 
- $\quad$ on the one hand, recruitment often does not follow from a systematic point of view, - $\quad$ on the other hand, there is often a lack of a targeted personnel development strategy.

The corporate culture also plays an important role in this context. This means above all the interaction, the way in which the process of performance creation takes place on the one hand, and on the other hand, how conflicts are handled [22].

For reasons of maximum objectivity, the vulnerability analysis should be carried out by a competent consultant (personnel consultant, management consultant).

\section{Valuation of the company}

First, it should be noted that there is no right evaluation procedure and no legal basis. However, it is an essential part of corporate finance.

The aim of a company valuation is to find a fair purchase price for the company - both from the point of view of the owner and from the point of view of the potential acquirer - or his shares, and then to coordinate safely, well-founded and comprehensible whether this purchase price and the resulting capital service can be generated from future company income. Otherwise, in the worst-case scenario, the purchase price could exceed the company's ability to capitalize. A future demise of the company would be preprogrammed [17].

The best-known methods of company valuation:

\section{Substance value methods:}

This is an attempt to determine the costs that would be incurred if the plant on the "green meadow" were to be rebuilt in its current state. The substance value method can be in the foreground in such cases, where the vast majority of the company's assets are tied up in real estate values and investments. Simplified, this can look like this:

Equation 1: Acquisition or Prod. costs = Debt capital + Estimated value of intangibles $=$ Substance value

\section{Liquidation value proceedings:}

It is assumed that the company will be abandoned. In this case, it is estimated what sales proceeds the assets can generate if they are sold individually. The sum of these estimated sales proceeds then represents the liquidation proceeds. This method ignores many costprice-enhancing factors.

\section{Earnings value method:}

This procedure has now become established and is recognized by the case law as the most sensible. This procedure includes the future-oriented earnings potential of the company in the determination of the purchase price. This procedure can be presented in a greatly simplified way:

1. Step: Determination of operating results for the last three years 
2. Step: Clean up operating results by extraordinary income and expenses

3. Step: Determination of adjusted average operating profit for the last three years

4. Step: Capitalization of the average operating profit of the last three years with an interest rate.

This interest rate should be based on the longest interest rate, e.g. of federal bonds plus an interest surcharge (to compensate the risk). See Equation 2 below:

Equation 2: Operating profit for the last three years $* 100$-Interest Rate

\section{Mean Method:}

The mean value method now tries to form an average value from the very different results from substance and earned value methods by weighting the substance value and the earned value and then adding them to the enterprise value. This is done by specifying, for example, that the yield value should have a weight of 75 percent of the total value. Consequently, the yield value shall be multiplied by 0.75 and the substance value by 0.25 . See Equation 2 below.

Equation 3: (earnings value $* 0.75)+($ substance value $* 0.25)=$ total value of the enterprise

\section{Proceedings under the capital service limit:}

This method, developed in practice, first determines the maximum sustainable additional capital service (additionally, because it exceeds the operational needs), which can be borne by the expected turnovers and revenues from the next 5-10 years. This additional portable capital service reflects an additional maximum loan volume that the company can bear. This loan volume now represents the upper price limit for the enterprise value.

In addition, combination value methods are more frequently used, which combine different evaluation methods with different weightings (based on findings of the past, the future, and the substance). 


\section{Creation of business plans}

Considering the potential of the future entrepreneur, planning of any necessary investments and their financing, product development, personnel qualification and organizational development, turnover, operating expenses, liquidity, capital service capacity, profitability, etc. This planning must show whether the purchase price of the company can be generated from the company's profitability. After all, the future entrepreneur will have to pay the purchase price on the grounds of his salary or profit allocations [16]. Therefore, the determination of the capital serviceability of the company in the context of the determination of business plans plays an essential role in determining the purchase price [24].

- Analysis of the tax framework

- $\quad$ Sale of business as a whole

- $\quad$ Concept of the essential operating basis

- $\quad$ Partial business disposal/- task

- Transfer of a co-entrepreneur's share

\section{Operation task as a whole}

The following statements deal with the tax treatment of business sales or business tasks. Such topics become relevant to traders whenever they decide to end their entrepreneurial commitment.

In addition to leasing or transferring the assets free of charge, it is possible to sell the holding to a purchaser or to terminate the holding in the context of a task [11].

The variant for which the entrepreneur chooses depends both on the company law agreements, on personal considerations of the entrepreneur and on legislative changes or situations.

The author has endeavored to present the tax consequences of a company succession as neutrally as possible, i.e. not only in Germany. The facts and concepts are, at least throughout Europe, congruent or transferable. Therefore, there are no references and quotations from legal norms and jurisdiction. In a later article, the topic is comprehensively dealt with in a German journal. 


\section{Sale of business as a whole}

A sale of the business occurs when a company with its essential operating bases is transferred to a purchaser for consideration. The transfer must be carried out in such a way as to allow the continuation of operations. is irrelevant. For the purposes of this provision, a partnership (e.g. OHG, KG or GbR) may be the exclusive of an individual [27].

The decisive factor for the assumption of a divestiture is that the essential operating basis as a unit is transferred entirely to the acquirer.

As a further condition, in addition to the transfer of operating bases, the trader must cease his activity. However, it is not assumed that the transferor ceases its commercial activity. Accordingly, the trader may continue another commercial activity unrelated to the divested activity unchanged.

\section{Concept of the essential operating basis}

The definition of existing assets as an essential operating basis can only be determined by individual decisions.

Whereas in the case of a division of the company, the business function of an asset is based exclusively on the operational function of an asset (so-called qualitative consideration), the concept of the essential basis of operations additionally includes the so-called quantitative approach. This includes all assets which, although insignificant for the economic operation, contain substantial hidden reserves. As a standard, therefore, company land is one of the main operating bases, irrespective of whether they are used for operational purposes [9].

\section{Partial business disposal/- task}

A sub-enterprise is an organically closed part of the holding, which is equipped with a certain degree of autonomy, which has all the characteristics of a holding and is viable on its own.

The sub-operation must therefore be conceptually distinguished from independent holdings and individual assets of working capital (operating equipment) [8].

For there to be a certain degree of economic autonomy(self-reliance), the various assets must be used in their summary for an activity which differs or differs from the rest of the commercial activity in the context of the whole business. Indications that speak in favor of self-reliance may include:

- Use of own fixed assets and resources

- Use of different personnel

- $\quad$ Existence of its own customer base

- $\quad$ Keeping your own books

As a final requirement, the company's own viability is required.

The partial operation task is to be delimited from this. The partial operation is carried out if the trader definitively ceases the activity previously carried out in the part-time operation and sells the essential operating bases devoted to the part-time operation to 
various purchasers within a short period of time or transfers the assets to the private assets and thus reveals all hidden reserves in one go [10].

\section{Transfer of a co-entrepreneur's share}

In addition to the sale of an entire business, a sub-business and a $100 \%$ shareholding in a corporation, the sale or abandonment of a co-contractor's share is also possible and taxable.

The co-entrepreneur's shareholding is to be surrendered if the co-entrepreneur's share is previously shared and then, by a single decision, sold to various purchasers [13].

\section{Operation task as a whole}

The business task must be distinguished from the sale of the company. Both methods of terminating a business lead to the same legal consequence but differ fundamentally in the previous implementation [3].

A business abandonment presupposes a definitive cessation of this commercial activity, as in the case of the sale of the business. This must be assumed if the trader sells the essential operating bases of the establishment.

The sale of these assets must not only take place uniformly to a single acquirer in the context of a task, but may, by way of derogation, be made to many purchasers [21].

Furthermore, there are the possibilities to transfer the assets into the private assets of the entrepreneur or to transfer the essential operating assets partly to sale and partly to private assets.

However, during the ongoing tasking process, the entrepreneur must ensure that the divestitures and withdrawals must take place in a uniform process. A uniform operation is to be assumed whenever the task is completed within a short period of time. It is not possible to determine exactly which period is still to be regarded as short [14].

The start of the operating edition shall be seen in actions which are objectively directed towards the dissolution of the undertaking. An internal task decision, even when an announcement to the outside world is made, does not therefore lead to the beginning of the operational task. The task ends when the last asset, which is part of the main operating basis, has been sold.

\section{Financing considerations}

- $\quad$ Financing the transfer of the company

- $\quad$ Financial instruments

- $\quad$ Financing the transfer of the company

The path into self-employment is often a rocky road. Because most of the time there is a lack of the necessary seed capital.

In the event of a start-up or start-up/takeover, priority financial instruments of state-owned start-up banks may be included, as the loans of these "founding banks" are endowed with favorable interest rates, grace-free start-up years and long maturities [18]. 
These funds will:

- $\quad$ Substance held in the company

- $\quad$ Profitability increased due to the lower interest burden and

- $\quad$ Liquidity is spared by delayed cash outflow. 185,000 start-up surges after the completion of the unit. The money seems to be falling on fertile ground: only 38 out of 1000 companies that received funds in the early 1990s were insolvent five years later.

\section{Financial instruments}

The financing elements are granted by house banks, but also in particular by promotional banks of the federal and state states. There are also consultants available for the right programs. May also be applied for reimbursement applications from public authorities for any consulting costs incurred. This support ensures that no company transferee must feel left alone [4].

\section{Self-capital assistance loans}

Ideal increase in equity. The amount of funds is limited. The amount of the "cover" and the other conditions (maturity, interest rate, collateral, etc.) may change over time.

\section{Start-ups}

Ideal credit for commercial founders/entrepreneurs and freelancers, entrepreneurs, and business successors. The conditions are like those of equity support. For example, investments such as stock expansion or market development costs are financed [7].

\section{Operating loan}

Ideal additions to investment financing. Cheap loans are granted to cover the additional equipment needs for pre-financing, warehousing, development costs, market development and payment targets.

The following principles apply for such loans:

- $\quad$ House banking principle: Applications for public loans must be submitted to a house bank before the start of the project.

- Apart financing: Only a part of the total investment is usually financed, so that the house bank's own funds and loans must be included.

- $\quad$ Collateral: As a rule, these loans are to be secured in the usual bank. However, there are exceptions due to special situations, as is currently applied due to the Covid19 exceptional situations.

For financing considerations and discussions with the banking partner, extensive preparatory work is necessary, which - if this cannot be handled alone - should be accompanied by professionally served consultants (tax consultants, auditors, Chamber of Commerce/HWK).

Documents to be prepared include, in particular:

- $\quad$ Project description (business concept) with investment plan

- $\quad$ Sales and earnings forecast (for approx. 2-3 years) incl. profitability forecast 
- $\quad$ Technical opinion (if necessary) external consultants/IHK or HWK

- $\quad$ Takeover and company contracts as well as leases and leases

- $\quad$ Financial statements and, if necessary, Opening balance sheet on takeover.

When using funding programs, care must be taken to ensure that deadlines are usually observed. Therefore, projects normally planned must only be implemented after public funds have been granted [28].

\section{Finding the successor}

Many takeovers are delayed, not materialized, or an emergency arises due to the sudden death of the entrepreneur, because many entrepreneurs are already resigning from the question of finding a successor.

\section{The successor is known}

Assuming that the successor is known, the following cases can be distinguished.

In many companies, although there is in principle a successor from the family, the potential successor lacks either the suitability or the will to take over the company.

In the case of a successor from the circle of shareholders, while maintaining the continuity of the company remains in principle, the emphasis is different from that of a successor to a family. In addition, the uninvolved potential successors often expect compensation for the renunciation of succession [7].

A suitable successor from the management or management level of the company often already has very good knowledge of the company. Continuity is therefore likely to be most widely maintained in this case. Professional aptitude and leadership qualification are also known. This solution is particularly useful if a suitable successor from the family is not available [15].

A successor from outside the company may be members of the management levels of companies in the same or related sector, as well as professionally and commercially qualified start-ups.

\section{The successor is unknown}

More difficult is the situation in which the successor is not known. Basically, the following ways may be possible:

- $\quad$ your own search (through the public, from the competition, associations, etc.)

- $\quad$ search via HR consultants

- $\quad$ search via exchanges of chambers of commerce and crafts.

Another alternative is to turn on a consultant: on the one hand, this saves time and prevents err on the other hand, on the other hand, the consultant can select the successor candidates based on a jointly developed requirements profile and present only the appropriate candidates to the entrepreneur. 


\section{Requirements for the successor}

Regardless of where the successor comes from, it must meet certain requirements.

Expertise is an important requirement for a successor. It consists of a commercial and a professional competence. Often, the successor is selected only according to this criterion.

The term social competence is used to summarize qualifications of the management silence. A new style of leadership cannot be prescribed, but is based on a willingness to talk, to be able to listen, to be able to relate to a clear position, to see one another as a role model and to be open. Talking to employees and managers, understanding their feelings and thoughts is an important, indispensable tool in this context. Therefore, decisionmaking, delegation and constructive conflict capability are among the requirements for a successor [20].

The most important requirements for the successor:

- $\quad$ Leadership skills / skills

- $\quad$ Social skills, willingness, and ability to talk

- $\quad$ Mediation and negotiation skills

- Business and professional competence

- He should fit to the team of the company no resistance already generates by his person

- Decision-making, assertiveness

- A clear concept should be presented by a successor to demonstrate his seriousness, but also his competence.

\section{Advantages / Disadvantages of alternatives of the transfer of companies}

Due to the many aspects to be considered, only the main advantages/disadvantages can be presented from the point of view of the company. 
Table 1: Type of Transfer - Advantages/Disadvantages - own depiction

\begin{tabular}{|c|c|c|c|c|c|c|c|c|}
\hline & $\begin{array}{l}\text { Shar } \\
\mathrm{e} \\
\text { deal }\end{array}$ & $\begin{array}{l}\text { Asse } \\
t \\
\text { deal }\end{array}$ & $\begin{array}{l}\text { Fusio } \\
\mathrm{n}\end{array}$ & $\begin{array}{l}\text { Operating } \\
\text { Splitting }\end{array}$ & $\begin{array}{l}\text { Operationa } \\
\mathrm{l} \\
\text { leasing }\end{array}$ & $\begin{array}{l}\text { Free } \\
\text { Transfer }\end{array}$ & $\begin{array}{l}\text { Family } \\
\text { Foundation }\end{array}$ & $\begin{array}{l}\text { Nonprofit } \\
\text { Foundation }\end{array}$ \\
\hline $\begin{array}{l}\text { Time and } \\
\text { Effort } \\
\text { high/low }\end{array}$ & + & + & & $+*$ & $\bullet$ & + & $+*$ & • \\
\hline $\begin{array}{l}\text { Preservation of the } \\
\text { Company } \\
\text { Secured/unsecured }\end{array}$ & + & • & & • & • & + & $+*$ & • \\
\hline $\begin{array}{l}\text { Tax burden } \\
\text { rather high/low }\end{array}$ & • & • & & $+*$ & + & + & $+*$ & + \\
\hline $\begin{array}{l}\text { Supply of the } \\
\text { Entrepreneur } \\
\text { secured/unsecured }\end{array}$ & • & $\bullet$ & & $\bullet$ & + & • & & • \\
\hline $\begin{array}{l}\text { Financing needs } \\
\text { rather high/low }\end{array}$ & • & + & & + & + & • & + & $\bullet$ \\
\hline $\begin{array}{l}\text { Request to } \\
\text { Successor } \\
\text { high/low }\end{array}$ & + & + & & • & + & • & • & • \\
\hline $\begin{array}{l}\text { Preservation of the } \\
\text { family } \\
\text { Assets secured } \\
\text { /ungesichert }\end{array}$ & • & + & & + & + & + & + & + \\
\hline Finding successors & • & + & & + & + & + & + & + \\
\hline
\end{tabular}

$+=$ rather an advantage

- = rather disadvantageous

* = depends on the method of payment of the purchase price (in an amount or in instalments)

A successor from outside the company may be members of the management level of companies in the same or related industries, as well as qualified start-ups. However, the assessment of the competence of the external

Harder. Nevertheless, this path is also a classic case for regulating the succession question.

\section{Discussion}

The literature analysis carried out in the context of this study clearly shows the reasons and strategies for an accompanying succession of entrepreneurs in Germany. It can be accepted as evidence that accompanied company succession must be regarded as unalterable due to the continuing complexity of the issue of business succession.

The present study has been able to identify the following reasons and strategies for a regulated succession of entrepreneurs in the literature using the qualitative content analysis according to Mayring. This adds to the existing literature in the field. 
The reasons for a regulated transfer of entrepreneurs must be distinguished between internal and external reasons. The most important internal reasons are the personal motives of the previous entrepreneur for a succession arrangement due to age and health status, as well as the lack of possibility of transition in the direct entrepreneurial family. This can also be seen in the works of Kay (2013 and (2016). The main external reasons for a regulated transfer of entrepreneurs were recognized as the increasing challenges of the current entrepreneur to continue to meet the ever-increasing demands in the field of tax and commercial law and to play a major role in shaping the advancing technological development of the existing company owner.

The most important components of the strategy of a planned transfer of entrepreneurs are the detailed consideration of the exit situation in relation to the form of the company and the desired transitional form, as well as the consideration and coordination of the precise objectives of the transfer of the entrepreneur between all parties involved as can be also seen in the works of Xian (2021) [28].

The research question of this article 'What are the reasons and strategies for finding a business successor considering the company analysis for small and medium-sized enterprises in Germany?' can therefore be regarded as fully answered.

\section{Conclusion}

The present study has clearly shown the reasons and strategies for finding a successor in Germany. Going beyond the core of this central research question, the following recommendations can be given, as they provide significant support for the planning, implementation, and full implementation of a regulated succession of entrepreneurs. Succession solutions cannot be implemented overnight and can take 3-5 years if the planning is well planned. The "lonely decisions" are often not the best. An entrepreneur is well advised to work hand in hand with special lists in the business sector as well as tax and commercial law for the transfer of the company.

The following recommendations for the rules on succession of entrepreneurs should be identified:

- $\quad$ Choose the right one, not the best, as your successor.

- $\quad$ Align the purchase price with the financial resilience of the company

- $\quad$ Get competent consultants "on board" to ensure professional competence and avoid one-sided "blinded" own view of things.

- $\quad$ Operate an open information policy 


\section{References}

[1] Astrachan JH, Klein SB, Smyrnios KX (2002) The F-PEC scale of family influence: a proposal for solving the family business definition problem. Family Bus Rev 1:45-48

[2] Atteslander P (2010) Methoden der empirischen Sozialforschung, 13. Aufl. Schmidt, Berlin

[3] Bieler S (2012) Psychologische Hürden der Unternehmensnachfolge aus Sicht des Senior-Unternehmers. In: Beckmann R, Brost $H$, Faust M (Hrsg) Unternehmensnachfolge im Mittelstand, 3. Aufl. Frankfurt School, Frankfurt am Main, S 17-36

[4] Brost H, Faust M (2012) Unternehmensnachfolge im Mittelstand - Daten und Fakten in Deutschland. In: Beckmann R, Brost H, Faust M (Hrsg) Unternehmensnachfolge im Mittelstand, 3. Aufl. Frankfurt School, Frankfurt am Main, S 3-15

[5] Brücker, H. u.A., (2013): Fachkräftebedarf in Deutschland., IAB-Stellungnahme 01/2013, Nürnberg

[6] Bundesverband der Deutschen Industrie e. V (Hrsg) (2014) Familienunternehmen.

[7] Coffman BA (2014) The family business succession model: an exploratory analysis of factors impacting family business succession preparedness, Manhattan.

[8] Diekmann A (2011) Empirische Sozialforschung - Grundlagen, Methoden, Anwendungen, 5. Aufl. Rowohlt, Reinbeck

[9] Ferrari, F. (2020). Exploring the side effects of socio-emotional wealth. A multilevel analysis approach to the dysfunctional dynamics in family business succession. International Journal of Entrepreneurship and Small Business, 40(1), 128146.

[10] Freund W (2000) Familieninterne Unternehmensnachfolge: Erfolgs- und Risikofaktoren. Gabler, Wiesbaden

[11] Halter F, Schröder R (2012) Unternehmensnachfolge in der Theorie und Praxis - Das St. Galler Nachfolge Modell, 3. Aufl. Haupt, Bern

[12] IHK NRW -Die Industrie- und Handelskammern in Nordrhein-Westfalen e.V. (Hrsg.) (2016): Von Generation zu Generation: Nachfolgegeschehen in NRW. IHK-Studie in Zusammenarbeit mit TNS Emnid und der FHDW Paderborn/Bielefeld, Düsseldorf

[13] Kay R., Spronovic O., Schlömer-Laufen, N., Rauch A. (2018): Unternehmensnachfolgen in Deutschland, Daten und Fakten Nr. 18; IFM, Bonn

[14] Kay, R. Suprinovic, O. (2013): Unternehmensnachfolgen in Deutschland 2014 bis 2018, Daten und Fakten Nr. 11; IFM, Bonn

[15] Kay, R.; Pahnke, A; Schlepphorst, S. (2016): Nachfolger gesucht: Wie Unternehmen ihre Nachfolge sichern; BMWi, Berlin, Netzwerktreffen 27.10.2016

[16] Klemisch, H., (2017): Mitarbeiterkapitalbeteiligung in Unternehmen -auf dem Weg zu einer Gesellschaft von Teilhabern“, (20.06.2017, Neue Mälzerei Berlin, Wissenschaftsladen Bonn

[17] Kuckartz, U., 2016. Qualitative Content Analysis. [in GER: Qualitative Inhaltsanalyse] [online]. 3., überarbeitete Auflage. Weinheim: Beltz Juventa. Grundlagentexte 
Methoden. ISBN 978-3-7799-3344-1 available under: http://www.contentselect.com/index.php?id=bib_view\&ean $=9783779943860$

[18] Leifels, A (2016) Alterung treibt Nachfolgebedarf im Mittelstand; KfW Research, Fokus Volkswirtschaft, Frankfurt/Main

[19] Laudien A, Schilling M (2012) Finanzinvestoren versus strategische Investoren. In: Beckmann R, Brost H, Faust M (Hrsg) Unternehmensnachfolge im Mittelstand, 3. Aufl. Frankfurt School, Frankfurt am Main, S 335-362

[20] Lubos G (2010) Psychologische Aspekte beim Generationenwechsel im Familienunternehmen - den Prozess der Verantwortungsübergabe richtig steuern. In: Schlecht \& Partner, Wessing T (Hrsg) Unternehmensnachfolge - Handbuch für die Praxis, 2. Aufl. Schmidt, Berlin, S 55-61

[21] Olbrich M (2014) Unternehmensnachfolge durch Unternehmensverkauf, 2. Aufl. Deutscher Universitäts-Verlag, Wiesbaden

[22] Porfírio, J. A., Felício, J. A., \& Carrilho, T. (2020). Family business succession: Analysis of the drivers of success based on entrepreneurship theory. Journal of Business Research, 115, 250-257.

[23] Schwartz,M. (2018): Generationswechsel im Mittelstand: Bis 2019 werden 240.000 Nachfolger gesucht, KfW Research, Fokus Volkswirtschaft, Frankfurt/Main

[24] Statistisches Bundesamt (2016): Bevölkerung und Erwerbstätigkeit, Ergebnisse des Mikrozensus zum Arbeitsmarkt, Jahr 2016), Fachserie 1 Reihe 4.1, Wiesbaden

[25] Schwarz, F. (2017): Thesis; Unternehmensnachfolge -Optionen, Planungsschritte und Strategien für kleine und mittlere Unternehmen, Duale Hochschule BadenWürttemberg, Lörrach

[26] Weber H (2009) Familienexterne Unternehmensnachfolge: eine empirische Untersuchung über die Akquisitionen von Familienunternehmen. Betriebswirtschaftlicher Verlag Gabler, Wiesbaden

[27] Wiesehahn A (2015) Erwartungen an die Unternehmensnachfolge aus Sicht der übergebenden und übernehmenden Personen: Ergebnisse einer empirischen Studie. In: Schriftenreihe des Fachbereichs Wirtschaftswissenschaften der Hochschule BonnRhein-Sieg, Bd 37. Sankt Augustin

[28] Xian, H., Jiang, N., \& McAdam, M. (2021). Negotiating the female successor-leader role within family business succession in China. International Small Business Journal, 39(2), 157-183. 